\title{
Seasonality variation of amputations in a university hospital from Monterrey, Mexico (2009-2012)
}

\author{
Variación estacional de las amputaciones en un hospital universitario de Monterrey, \\ México (2009-2012)
}

\section{Sandra Castillo-Guzmán ${ }^{1 *}$, Dionicio Palacios-Ríos ${ }^{1}$, Norma G. López-Cabrera1,} Marco A. Hernández-Guedea ${ }^{2}$, Nora H. Rodríguez-Rodriguez ${ }^{1}$ and Omar González-Santiago 3

${ }^{1}$ Anesthesiology Department; ${ }^{2}$ General Surgery Department. Hospital Universitario Dr. José E. González; ${ }^{3}$ Pharmacy Postgraduate Program, of Chemical Sciences, Universidad Autónoma de Nuevo León. Monterrey, Nuevo León, Mexico

\begin{abstract}
\end{abstract}
Background: The amputation of an extremity is a main complication of Diabetes mellitus. Worldwide the prevalence of amputations associated with diabetes mellitus is variable and had a considerable impact in the quality of life. Objective: Analyze the frequency of amputations in the University Hospital, Dr José E González and evaluate if a seasonal pattern is present. Method: A retrospective analysis from 2009 to 2012 was carried out. Clinical files of diabetic patients undergoing to amputation were studied. The seasonality was evaluated with a chi square goodness of fit. Results: A total of 456 amputations. Were studied. Results shown that February was the month with highest frequency of amputations while winter was the annual season with highest frequency of amputations. Conclusions: Amputations of diabetic patients from Metropolitan Monterrey Mexico show a seasonal pattern being the winter months those that present highest frequency.

KEY WORDS: Diabetes. Amputations. Seasonality. Winter. Mexico.

\section{Resumen}

Antecedentes: Una de las principales complicaciones de la diabetes mellitus es la amputación de alguna extremidad. Enłodo el mundo, la prevalencia de amputaciones asociadas a la diabetes es muy variada y tiene un impacto considerable en la calidad de vida del paciente. Objetivo: Analizar la frecuencia de las amputaciones en el Hospital Universitario Dr. José E. González y evaluar si se presenta un patrón estacional. Método: Se realizó un estudio retrospectivo de 2009 a 2013 en el que se revisaron los expedientes de pacientes diabéticos que se sometieron a amputación. La estacionalidad se analizó con la bondad de ajuste de ji al cuadrado. Resultados: Se analizaron 456 amputaciones. Los resultados muestran que febrero es el mes que presenta la mayor frecuencia de amputaciones. La estación anual con mayor número de amputaciōnes fue el invierno. Conclusiones: Las amputaciones en pacientes diabéticos del área metropolitana de Monterrey presentàn un patrón estacional, siendo los meses de invierno los de mayor frecuencia.

PALABRAS CLAVE: Diabetes. Amputaciones. Estacionalidad. Invierno. México.

\section{Correspondence:}

*Sandra Castillo-Guzmán

Madero y Gonzalitos s/n, Mitras centro

C.P. 64460, Monterrey, N.L., México

E-mail: castilloguzsan@yahoo.com
Date of reception: 24-01-2018

Date of acceptance: 05-06-2018

DOI: $10.24875 / C I R U E . M 18000060$
Cir Cir. 2018;86:349.353

Contents available at PubMed www.cirugiaycirujanos.com 


\section{Introduction}

Diabetes mellitus is a disease of epidemic proportions that has doubled its worldwide incidence in the last 10 years. According to World Health Organization data, 422 million adults were estimated to suffer from diabetes in 2014, and it was the cause of 1.5 million deaths in $2012^{1}$. The complications of this disease affect many parts of the body and, in general terms, this increase mortality in those who from suffer it. The complications that occur include the following: kidney failure, myocardial infarction, stroke, vision loss, peripheral nerve damage and an increased risk of non-traumatic amputation². These complications are associated with neuropathy, peripheral vascular disease, poor metabolic control and immune system impairment. All these factors can lead, in case of foot complications, to ulceration, infection and, eventually, amputation. Amputation seasonal variation is not well described.

Amputation of a lower extremity is one of the complications most feared by patients with diabetes, and is associated with a poor quality of life. The incidence of amputations in diabetic patients is highly varied: an overall rate ranging from 46.1 to 9,600 amputations per 100,000 population has been estimated, which is a considerably high figure if compared with the incidence of amputations in the general population, which is 5.8 to 31 amputations per 100,000 population. Compared with the general population, diabetes patients have a 30 -fold higher risk of having a non-traumatic amputation ${ }^{3}$. In developing countries, amputation is regarded to involve financial ruin for the patient family ${ }^{4,5}$.

Given the considerable impact amputations have, the purpose of this study was to describe, monthly and by annual season, the frequency of non-traumatic lower extremity amputations in patients with diabetes mellitus.

\section{Method}

The number of amputations in patients with diabetes, as well as their sociodemographic data, were obtained from the medical records department of Dr. José E. González University Hospital, of the Autonomous University of Nuevo Leon. The study period was from January 2009 to December 2012.

The number of monthly amputations, as well as per season of the year, was adjusted to 30 and 90 days, respectively. Amputations were grouped monthly and by season of the year according to gender, age $(>60$
Table 1. Frequency of amputations at Dr. José E. González University Hospital (2009-2012)

\begin{tabular}{|c|c|c|}
\hline Variable & Frequency & p \\
\hline Gender & & $\bar{\sigma}$ \\
\hline Males & 310 & $<0$. \\
\hline Females & 148 & $\stackrel{1}{2}$ \\
\hline Age (years & & (2) \\
\hline$<60$ & 234 & \\
\hline$>60$ & 223 & 0.61 \\
\hline Level of education & & 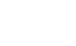 \\
\hline Illiterate & 41 & $\frac{0}{5}$ \\
\hline Primary school & 226 & 으 \\
\hline Secondary-school & 90 & $\stackrel{0}{\simeq}$ \\
\hline High school-college & 41 & $<0.01$ \\
\hline Marital status & & $\subseteq$ \\
\hline Married & 262 & $\cdot \frac{\overline{0}}{n}$ \\
\hline Widower & 59 &.$\cong$ \\
\hline Single/Divorced & 109 & $<0.01$ \\
\hline Surgery & & อి \\
\hline One or more toes & 82 & $\subset$ \\
\hline Supramalleolar & 34 & $\stackrel{\oplus}{+}$ \\
\hline Transtibial & 110 & \pm \\
\hline Supracondylar & 230 & $<0$ \\
\hline
\end{tabular}

or $<60$ years), level of education (illiterate, primary, secondary and high school-college), marital status (single-separated, married and widowed) and the type of surgery (one or more toes, supramalleolar, supracondylar and transtibial). The elementary analysis is observational, descriptive and retrospective. Monthly and seasonal difference according to the different groups was analyzed with the chi-square goodness of fit test. The risk of amputation in winter with regard to summer was analyzed with a logistic regression and was expressed as the odds ratio (OR).

The study was approved by the Autonomous Üniversity of Nuevo León Faculty of Medicine Ethics Committee, with registration number AN14-002.

\section{Results}

\section{Population characteristics}

During the study period, 456 non-traumatic amptrtations were performed in patients with diabetes mellitus. The main amputation site was supracondylar $(50.4 \%)$, while the least common type was one or more toes (18\%). The highest percentage of amputations was observed in men (67.8\%), in subjects ofder than 60 years $(48.8 \%)$, with only primary school education $(56.8 \%)$ and married (61\%). With the exception of age, a significant difference was observed in the rest of the groups $(p<0.05)$ (Table 1$)$. 
Table 2. Number of amputations according to the month

\begin{tabular}{|c|c|c|c|c|c|c|c|c|c|c|c|c|c|}
\hline Variable & January & February & March & April & May & June & July & August & September & October & November & December & p \\
\hline \multicolumn{14}{|l|}{ Gender } \\
\hline Males & 15 & 25 & 9 & 13 & 17 & 8 & 12 & 9 & 13 & 11 & 6 & 10 & $0 . \bar{\theta} 2$ \\
\hline Females & 27 & 41 & 31 & 28 & 19 & 20 & 22 & 30 & 27 & 22 & 22 & 17 & 0,06 \\
\hline \multicolumn{14}{|l|}{ Age (years) } \\
\hline$<60$ & 16 & 36 & 16 & 17 & 17 & 18 & 20 & 21 & 21 & 16 & 15 & 16 & 0.86 \\
\hline$>60$ & 26 & 29 & 23 & 24 & 19 & 10 & 14 & 17 & 19 & 16 & 12 & 11 & 0,02 \\
\hline \multicolumn{14}{|l|}{ Level of education } \\
\hline Illiterate & 4 & 9 & 3 & 4 & 4 & 4 & 3 & 1 & 3 & 4 & 2 & 1 & 0.27 \\
\hline Primary school & 28 & 26 & 20 & 18 & 17 & 14 & 15 & 19 & 24 & 15 & 13 & 13 & $0 \pm 6$ \\
\hline Secondary school & 4 & 15 & 5 & 9 & 9 & 5 & 9 & 10 & 8 & 6 & 5 & 6 & 0.24 \\
\hline High school/college & 6 & 9 & 4 & 3 & 1 & 2 & 3 & 4 & 1 & 4 & 2 & 3 & $0 \frac{9}{1} 5$ \\
\hline \multicolumn{14}{|l|}{ Marital status } \\
\hline Married & 29 & 44 & 22 & 19 & 23 & 19 & 17 & 23 & 25 & 15 & 16 & 7 & 0.001 \\
\hline Widowed & 5 & 10 & 4 & 10 & 5 & 3 & 2 & 4 & 2 & 7 & 3 & 5 & 0.93 \\
\hline Single/divorced & 9 & 10 & 10 & 10 & 7 & 5 & 12 & 10 & 11 & 8 & 6 & 12 & 0.87 \\
\hline \multicolumn{14}{|l|}{ Surgery } \\
\hline One or more toes & 9 & 11 & 7 & 4 & 6 & 7 & 3 & 6 & 5 & 13 & 4 & 8 & 0.23 \\
\hline Supramalleolar & 1 & 5 & 4 & 1 & 3 & 3 & 4 & 3 & 1 & 2 & 3 & 4 & 0,8 \\
\hline Supracondylar & 25 & 30 & 22 & 24 & 23 & 13 & 13 & 20 & 21 & 13 & 12 & 12 & 0,02 \\
\hline Transtibial & 10 & 14 & 5 & 12 & 5 & 6 & 13 & 9 & 12 & 8 & 11 & 6 & 0.7 \\
\hline
\end{tabular}

Table 3. Number of amputations by season of the year

\begin{tabular}{lccccc}
\hline & Spring & Summer & Autumn & Winter & $\mathbf{p}$ \\
\hline Gender & & & & & \\
$\quad$ Females & 39 & 32 & 27 & 48 & 0.08 \\
$\quad$ Males & 71 & 77 & 65 & 93 & 0.13 \\
Age (years) & & & & & \\
$\quad<60$ & 51 & 61 & 48 & 70 & 0.16 \\
$>60$ & 58 & 47 & 44 & 71 & 0.04 \\
& & & & & \\
Level of Education & & & & & \\
Illiterate & 14 & 5 & 9 & 13 & 0.18 \\
$\quad$ Primary school & 48 & 57 & 44 & 74 & 0.02 \\
$\quad$ Secondary school & 22 & 27 & 17 & 22 & 0.52 \\
$\quad$ High school/college & 8 & 9 & 7 & 17 & 0.11 \\
$\quad$ & & & & & \\
Marital status & & & & & \\
$\quad$ Married & 63 & 64 & 45 & 86 & 0.001 \\
$\quad$ Widowed & 16 & 10 & 12 & 20 & 0.25 \\
$\quad$ Single/divorced & 23 & 29 & 27 & 28 & 0.86 \\
& & & & & \\
Surgery & & & & & \\
$\quad$ One or more toes & 15 & 12 & 20 & 23 & 0.24 \\
$\quad$ Supramalleolar & 3 & 6 & 4 & 8 & 0.42 \\
$\quad$ Supracondylar & 61 & 50 & 35 & 69 & 0.007 \\
$\quad$ Transtibial & 19 & 27 & 25 & 25 & 0.68 \\
\hline
\end{tabular}

\section{Monthly amputations}

According to the month, the highest percentages of amputations occurred in January and February (9.6 and $13.4 \%$, respectively), while the lowest were observed in June and July (6.1 and $7.7 \%$, respectively). Monthly difference was statistically significant in the female gender $(p=0.04)$, in subjects older than 60 years $(p=0.03)$ and in hose who were married $(p<0.01)$ (Table 2).

\section{Seasonal amputations}

In general, the highest frequency of amputations was observed to occur in the winter season, with the lowest frequency being recorded in summer. This seasonal difference was statistically significant only in those who only had primary school education $(p=0.04)$ and in married subjects $(p<0.01)$. The rest of the groups showed no significant difference fTa- $^{\circ}$ ble 3). The risk for amputation in winter with regard to summer was statistically significant in people with önly secondary school education $(\mathrm{OR}=3.31 ; 95 \%$ confidence interval: 1.02-10.69).

\section{Discussion}

This study describes non-traumatic amputations monthly variation, as well as by season of the year, in patients with diabetes mellitus in a northeastern Mexico tertiary care hospital. Several physiological and pathological processes have shown seasonal variation in both healthy and in sick people. Examples of this are cortisol, adrenaline, glucose, blood pressure, heart rate and glycosylated hemoglobin ( $\mathrm{HbA} 1 \mathrm{c})$ yalues, among others ${ }^{6}$. A seasonal pattern has even been reported in the incidence of type 2 diabetes? 
As in other studies, the percentage of amputations was higher in the male than in the female gender ${ }^{8-10}$. Possible causes of this difference could be deficient foot care by males, inappropriate habits such as not adhering to an adequate diet for their illness, and also not having periodic measurement of their blood glucose and lipid values ${ }^{11,12}$.

In this study, a significant difference was observed in the frequency of monthly and seasonal amputations. To date, there are few studies that analyze the frequency of amputations from a temporal perspective in patients with diabetes mellitus. Even when a difference is reported according to the season of the year, there is contradiction regarding the season when the largest number of amputations occurs. One study in New York reported that the highest frequency of amputations occurred in spring, which differs from our findings ${ }^{13}$. On the other hand, one study in Hong Kong found a positive association between the frequency of amputations and ambient temperature, suggesting that warm weather months are associated with a larger number of amputations; however, the authors consider that the country's characteristic high humidity could mask the effects of temperature ${ }^{14}$. Another study in Pakistan reported the highest frequency of amputations in winter, which agrees with our study ${ }^{15}$.

Several factors can influence on amputation seasonal variation; among these, temperature and the degree of humidity might be considered two important factors. Exposure to cold temperatures might affect blood perfusion of the patients' extremities, and high humidity can favor conditions for infection of these extremities. However, most investigations thus far do not accurately explain the causes or factors of such seasonal variation. More studies are needed in this regard considering other variables, such as metabolic control, since this factor is known to significantly influence on amputation risk. It should be noted that, in Mexico, $70 \%$ of patients do not have an adequate metabolic control and many of them do not properly inspect their feet ${ }^{16}$.

Knowing amputations seasonal variation might help decision makers to design preventive strategies, especially in the winter season of the Monterrey metropolitan area. Scheduling visits before and during the winter months, and advising patients more thorough inspection of their feet during this period, might contribute to a substantial improvement.

Finally, the limitations of this studio should be considered. Among them, we can mention that our results may not apply to other cities of Mexico or the world, and caution in their interpretation is therefore recommended. In addition, an analysis of meteorological variables such temperature and humidity was not inclưded in our study. Metabolic control data, such as HbÂAc levels, were not available, and neither were the conditions of healthcare services provision, e.g. Mexican Institute of Social Security, Ministry of Health or other institutions. All these factors might influence on amputation seasonal variation as well.

\section{Conclusions}

The frequency of amputations in diabetic patients of the Monterrey metropolitan area exhibits a seasonal pattern, with the winter months showing the largest number of amputations.

\section{Acknowledgements}

To Ramiro A. Torres Villarreal, Asahel Alonso Alänís and Teresa A. Nava Obregón, for the technical support.

\section{Conflicts of interests}

The authors declare that they have no conflicts of interest.

\section{Ethical disclosures}

The study was approved by the Ethics Committee of the Faculty of Medicine of the Autonomous University of Nuevo León, with registration number AN14-002.

Informed consent: since the study is retrospective in nature, informed consent was not requested.

\section{References}

1. Roglic G. Global report on diabetes. Geneva, Switzerland: World Health Organization; 2016.

2. Forbes JM, Cooper ME. Mechanisms of diabetic complications. Physiol Rev. 2013;93:137-88.

3. Moxey PW, Gogalniceanu P, Hinchliffe RJ, Loftus IM, Jones KJ, Th̆ompson MM, et al. Lower extremity amputations - a review of globall variability in incidence. Diabet Med. 2011;28:1144-53.

4. Driver VR, Fabbi M, Lavery LA, Gibbons G. The costs of diabetic foot: the economic case for the limb salvage team. J Vasc Surg. 2010;52(3 Suppl):17S-22S.

5. Kerr M, Rayman G, Jeffcoate WJ. Cost of diabetic foot disease to the National Health Service in England. Diabet Med. 2014;31:1498-504.

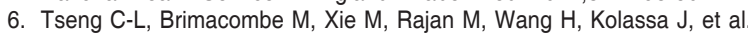
Seasonal patterns in monthly hemoglobin A1c values. Am J Epidemiol. 2005;161:565-74.

7. Doró P, Benko R, Matuz M, Soós G. Seasonality in the incidence of type 2 diabetes: a population-based study. Diabetes Care. 2006;29:173.

8. Ebskov LB. Epidemiology of lower limb amputations in diabetics incDenmark (1980 to 1989). Int Orthop. 1991;15:285-8. 
9. Trautner C, Haastert B, Mauckner P, Gätcke L-M, Giani G. Reduced incidence of lower-limb amputations in the diabetic population of a German city, 1990-2005: results of the Leverkusen Amputation Reduction Study (LARS). Diabetes Care. 2007;30:2633-7.

10. Veresiu IA, lancu SS, Bondor C. Trends in diabetes-related lower extremities amputations in Romania - a five year nationwide evaluation. Diabetes Res Clin Pract. 2015;109:293-8.

11. Rossaneis MA, Haddad M do CFL, Mathias TA de F, Marcon SS. Differences in foot self-care and lifestyle between men and women with diabetes mellitus. Rev Lat Am Enfermagem. 2016;24:e2761.

12. Mathew R, Gucciardi E, De Melo M, Barata P. Self-management experiences among men and women with type 2 diabetes mellitus: a qualitative analysis. BMC Fam Pract. 2012;13:122.
13. Armstrong DG, Lavery LA, van Houtum WH, Harkless LB. Seasonal variations in lower extremity amputation. J Foot Ankle Surg. 1997; 36:146-50.

14. Leung HB, Ho YC, Wong WC, Guerin J. Seasonal variations in non-traumatic major lower limb amputation in Hong Kong Chinese diabetie patients. Hong Kong Med J. 2007;13:379-81.

15. Ateeq S, Mehmood R. Seasonal variations and hospitalization due to diabetic foot complications. JRMC. 2013;17:201-3. Disponible en: https:// www.journalrmc.com/volumes/1395217808.pdf

16. Vargas-Daza ER, Rivera-Pérez MDP, Villarreal-Ríos E, Galicia-Rodríguez L, Martínez-González L. Exploración física y morbilidad de miembros pélvicos en el paciente diabético tipo 2. Rev Med Inst Mex Seguro Soc. 2013;51:314-9. 